\title{
Symbolic Innovation: The Notation of Jacob de Senleches
}

\author{
JASON STOESSEL (ARMIDALE)
}

\begin{abstract}
Sic nunc successive venientes, habentes et intellegentes que primi magistri relinquerunt maiores subtilitates per studium sunt confecti ut quod per antecessores imperfectum relictum fuit per successores reformetur. ${ }^{1}$
\end{abstract}

With this statement, the late fourteenth century anonymous author of the Tractatus Figurarum concludes his prologue. ${ }^{2}$ The subsequent chapters in this treatise detail a rich vocabulary of novel signs used to achieve a new, subtle rhythmic freedom. From the grammatical tense of the previous passage, it is clear that this treatise is concerned with innovations that have already occurred. While very few of the actual signs in the treatise are found in the surviving sources containing this repertoire, the concerns expressed by the author of the Tractatus clearly reflect the notational situation apparent in surviving works in the ars subtilior style. Prior to the twentieth century, no greater diversity of notational signs (figure) $)^{3}$ are found in a mensural context than in the surviving versions of works by Jacob de Senleches, his contemporaries and his immediate successors. The use of special figures in his La harpe de melodie and En attendant esperance is only exceeded by Rodericus' Angelorum psalat and matched by the works of composers such as Guido $(\mathrm{Ch} 27,28) .{ }^{4}$ The compositions of Matheus de Perusio

\footnotetext{
1 'Thus, those now coming after, possessing and understanding that which the first masters left behind, have accomplished by study greater subtleties so that which was left imperfect by predecessors might be reformed by those who follow them.', P.E. SCHREUR (ed.), Tractatus Figurarum. = Greek and Latin Music Theory 6 (Lincoln and London 1989), p. 68.

${ }^{2}$ With regards to the dating of the treatise, the earliest source appears to be the Chicago, Newberry Library Ms. 54.1 given a terminus post quem of 1391. q.v. K. VON FISCHER, Eine wiederaufgefundene Theoretikerhandschrift des späten 14. Jahrhunderts, in: Schweizer Beiträge zur Musikwissenschaft 1.1 (1972), p. 28. Ursula Günther's terminus post quem of 1375 for this treatise must be disregarded in light of Schreur's examination of the transmission of the Tractatus Figurarum and the fact that the citation of the motet Rex Carole, upon which she bases her observation, occurs in only the Faenza MS from 1473-74, and not in earlier sources. See Günther's statements in her The Motets of the Manuscripts Chantilly musée condé (olim 1047) and Modena, Biblioteca estense a, M.5,24 (olim lat. 568) = Corpus Mensurabilis Musicae 39 (Rome 1965), p. XXXb. See Schreur's critical notes and discussion of transmission in Schreur, op.cit., p. 66 \& pp. 59-63; On the authorship of the Tractatus vid. ibid., pp. 3-9.

${ }^{3}$ Medieval Latin orthographies are used throughout this paper.

${ }^{4}$ Manuscript sigla are used in this article as follows:

Ch Chantilly, Musée Condé, ms 564 (olim 1047) = Codex Chantilly

(RISM \# F-CH 564)

Chic Chicago, Newberry Library, ms 54.1 (RISM \# US-Cn 54.1)

Mod Modena, Biblioteca estense e Universitaria, ms a.M.5.24 (RISM \#

I-MOe5.24

Pit Paris, Bibliothèque Nationale, fonds italien 568

$P R \quad$ Paris, Bibliothèque Nationale, fonds nouvelle aquisition française 6771

= Codex Reina (RISM \# F-Pn 6771).
} 
also show a great variety of signs. ${ }^{5}$ However, as observers of this repertoire, we are left few clues when deciphering the meaning of the many special figures, frequently peppered throughout the repertoire, due to the paucity of contemporary record concerning their nature and origin.

One purpose of this paper is to examine the meaning of those special figures and coloration, which occur in the works ascribed to the late fourteenth century composer Jacob de Senleches, drawing on theoretical discussion from the period and observing principles in sources inherited from both notational traditions of the French Ars nova and early Italian trecento. The examination of technical problems occurring in the realisation of the notation was primarily motivated by Laurie Koehler's criticism of Gordon K. Greene's transcription of En attendant esperance, namely that "each note of a specific form and color <sic $>$ has a consistent value throughout $<E n$ attendant esperance $>$ ". In a broader sense, these special signs represent discrete, unequivocal values within the cultural context of the music inside the bounds of the music's mensuration and they are unlikely to be duplicating another form unless there is a logical purpose. ' It is abundantly clear that in most cases the context of the figures was important, as was emphasised by the theorists usually examining special forms in the context of a certain tempus or prolation.

The other purpose of this paper is to examine why particular forms were used and their historical foundations. Two theoretical treatises from this period figure prominently in the examination of this style's notation. They are the aforementioned Tractatus Figurarum and Tractatus de figuris et temporibus. When considering these two tracts, the question arises of whether the system which is described by these treatises is inherently Italian or French in its conception. While the author may have been Italian, it seems likely that the Tractatus Figurarum represents a French system especially when considering its use of a French word traynour which stems from the verb trainer ('to drag, draw out'). ${ }^{8}$ It is also evident that the author of this treatise is seeking to rationalise a set of recently invented figures. Furthermore, the Tractatus de figuris et temporibus refers to the same forms in the Tractatus Figurarum as figure francigene ('French

The inventories of Codex Chantilly are found in G. REANEY, The Manuscript Chantilly, Musée Condé, in: Mus. Disc. VIII (1954), pp. 88-95, and IDEM (ed.), Manuscripts of Polyphonic Music (c.1320 1400). = Repertoire internationale des sources musicales BIV 2 (Munich-Duisburg 1969), pp 128-160. The item numbers given in this study apply to both inventories. URSULA GÜNTHER's inventory, Das Manuskript Modena, Biblioteca Estense a.M.5,24 (olim lat 568= Mod), in: Mus. Disc. XXIV (1970), of Mod, and KURT VON FISCHER's The Manuscript Paris, Bibl. Nat., nouv. acq. frç. 6771 $($ Codex Reina $=$ PR) in: Mus. Disc. XI (1957), pp 38-78 are used throughout this article.

${ }^{5}$ W. APEL (ed.), French Secular Music of the Late Fourteenth Century (Cambridge/Massachusetts 1950), p. 8a.

${ }^{6}$ L. KoEHLER, Review: Gordon K. Greene, Polyphonic Music of the Fourteenth Century, XVIII-XX, etc., in: JAMS 39 (1986), p. 636.

${ }^{7}$ The author of this study regards this practice as a musical manifestation of the principle known as Ockham's Razor (Pluritas nunquam ponenda est sine necessitate ponendi). For an excellent thesis regarding the influence of Ockamite thinking on the music of the fourteenth century vid. D. E. TANAY, Music in the age of Ockham: The interrelations between music, mathematics, and philosophy in the fourteenth century (Ph.D. University of California 1989).

${ }^{8}$ Traynour would appear to refer to the practice of syncopation (i.e. division of time) using proportional notation. q.v. SCHREUR, op. cit., pp. 20-24. Schreur maintains that the treatise has an Italian author, ibid., p. 7. 
notes' ${ }^{\prime},{ }^{9}$ indicating that in the theorist's mind these were true French forms, and were not borrowed from Italian music.

Anne Stone has recently argued that the author of the Tractatus Figurarum is seeking to redivide the brevis through invented figures in a process which she sees as analogous to Italian trecento notation. ${ }^{10}$ While it is reasonable to suppose that Italian music influenced the music of the ars subtilior, the author of this article maintains that the musical figures per se are essentially French in their conception for the very reason that they rely on the principle of small notes, that is the minima and semiminima, which have an absolute value regardless of the mensuration. This concept is clearly foreign to the trecento notion of a constant brevis with various divisiones and without absolute values smaller than a brevis. Thus the actual role of Italian notation in the formation of these note forms is negligible and the notational devices used to construct the figures in the Tractatatus Figurarum are based on the principles of French notation.

It is proposed that the figures in Senleches' music are also essentially French in that they rely on the extension of the principles of French ars nova notation. This view openly contests many scholars' assertions that the forms encountered in these treatises and pieces in the repertoire are Italianate. Particular focus on this problem is found in Günther's and Stone's discussions of Guido's Or voit tout en aventure (Ch 28). ${ }^{11}$ Significantly, the text of this work employs the verb traire, which is closely related to traynour which is found in the Tractatus figurarum. While Günther argues that the text can be interpreted from the viewpoint of an Italian composer who was seeking to free himself from the restrictions of

\footnotetext{
${ }^{9}$ Anonymous, Tractatulus de figuris et temporibus, 3b.21, in F. A. Gallo (ed.), Mensurabilis Musicae Tractatuli. = Antiquae Musicae Italicae Scriptores I (Bologna 1966).

${ }^{10}$ A. STONE, Writing Rhythm in Late Medieval Italy: Notation and Musical Style in the Manuscript Biblioteca Estense, Alpha.M.5.24 (Ph.D. Harvard University 1994), p. 203.

${ }^{11}$ The text with translation drawing heavily on Anne Stone, op.cit., p. 170, cf. U. GÜNTHER, Das Ende der ars nova, in: Mf XVI (1963), pp. 107 f., is as follows:

Or voit tout en aventure

Puis qu'[a]insi me conveient fayre

A la nouvelle figure

Qui doit a chascun desplayre.

Que c'est trestout en contraire

de bon art qui est parfayt:

Certes ce n'est pas bien fayt.

Nos faysons contre nature de ce qu'est ben fayte deffayre; Que Philipe qui mais ne dure Nos dona boin examplaire.

Nos laisons tous ses afayres Por Marquet le contrefayt.

Certes ce n'est pas bien fayt.

L'art de Marquet n'a mesure, N'onques riens ne sant parfayre; C'est trop grant outrecuidure D'ansuir et de portayre Ces figures, et tout traire L'oull varieus de bon trayt. Certes ce n'est pas bien fayt.

Now everything is left to chance Because it is thus necessary for me to compose with the new figures which displease everyone. It is completely contrary To the good art which is perfect. Certainly this is not done well.

We compose against nature to destroy that which is done well. For which Philippe, who just died, gave us a good example. We lay aside all his works Because Marchettus does the opposite. Certainly this is not done well.

Marchettus' art has no measure and never can anything be perfected. It is very presumptious to follow and to draw these figures, and to drag the eye away from the good manner. Certainly this is not done well.
} 
French notation, ${ }^{12}$ Stone contends that the work could be a parody of the ars subtilior style itself. ${ }^{13}$

However, Stone's insistence that the figure caudate in this work are meaningless is contestable. ${ }^{14}$ As shall be shown below, the subtle division and grouping of divisions, which she views as meaningless, were fundamental to many special note forms in this repertoire, especially in Senleches' music, and intrinsic to the subtle division of time. The diversity of signs is not the mere yearning for complexity but instead, as suggested by the author of the Tractatus Figurarum, represents the achievement of a school of composition seeking to capture and enhance the subtleties of musical performance at the rhythmic level. In the case of

Guido's composition, the distinction between the forms

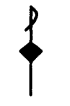

and $f$, which represent the same duration, lies in respectively the two-fold and three-fold division of prolation..$^{15}$

In many respects, the text of Or voit tout suggests, through the device of $l i$ totes, that the musician is abandoning the dogma of the traditions of both musical figureheads mentioned in the text, namely Philippe de Vitry and Marchettus de Padua, and in doing so, he "creates" a new notation which embraces the freedoms of both Italian and French music through the invention of new note forms. The text of Or voit tout en aventure could equally describe the plight of a French composer wishing to extend his notation beyond the confines of his indigenous notation, thereby seeking to reproduce the freedom apparent in Italian music's division of time. Such a composer is Jacob de Senleches.

\section{Coloration and Particoloured figures}

With the advent of the French ars nova, the invention of a new device enabled proportional relationships contrasting with the inherent mensuration in a piece of music to be notated using different coloured inks. This is termed coloration. The earliest known example of this device is found within Philippe de Vitry's Garrit gallus/In nova fert animus/ [Neuma] in the Roman de Fauvel, ${ }_{16}^{16}$ where notes written in solid red ink rather than the usual black ink are used to indicate a 2:3 proportion within the modus. This early usage amounted to a reversal of tempus, whereby the perfect tempus becomes imperfect, and vice versa. Void black notes (note vacue) were initially equivalent to full red notes, ${ }^{17}$ and appear to be favoured by Italian scribes, although, on the basis of the red notation in Mod and

\footnotetext{
${ }_{12}^{12}$ GÜNTHER, Das Ende der ars nova, p. 111.

${ }^{13}$ STONE, op. cit., p. 177.

${ }^{14}$ STONE, op. cit., pp. 173-175.

${ }^{15}$ cf. GÜNTHER, Das Ende der ars nova, p. 109.

${ }_{17}^{16}$ Paris, Bibliothèque Nationale, fonds frç. 146, f. $44 \mathrm{v}$ (= Roman de Fauvel).

${ }^{17}$ For example, de Vitry's aforementioned piece in the Roman de Fauvel, which is notated using red ink for coloration, is also found in the ms Paris, Bibliothèque Nationale, Collection de Picardie, ms 76, f. $67 \mathrm{r}$ [facsimile found in F. GENNRICH, Übertragungsmaterial zum Abriß der Mensural Notation des XIV. und der Ersten Hälfte der XV. Jahrhunderts. = Musikwissenschaftliche Studienbibliothek 4 (Langen bei Frankfurt 1965), Tafel III], where black void forms are used in the place of the red forms.
} 
$C h$, it appears that Italian scribes frequently adopted the French practice towards the end of the century. ${ }^{18}$

The ars subtilior saw coloration being used in new ways and with new forms. In Senleches' music, as with much of the music of his contemporaries, not only red and void black figures occur in the same piece, but also void red and particoloured figures, the latter being notes or ligatures where one part is black and the other void or full red. ${ }^{19}$ Red or void black notes, particularly minime, were at times used to prevent alteration or imperfection. This device is similar to the punctus divisionis and relies on the equivalence of red (or void black) minime to black minime. Another application sees an extension of the proportional properties of coloration to create passages in diminution or augmentation.

In order to understand the use of isolated coloured notes, one needs to firstly look at the punctus ('dot') and syncopatio theory. In this period, the use of the dot in French music had two functions. In his Tractatus Practice De Musica Mensurabili, Prosdocimus de Beldemandis states that there are two types of puncti, namely the punctus perfectionis (p.p.) and the punctus divisionis (p.d.). ${ }^{20}$ The p.p. is also called the punctus additionis. The p.p. is used after a note that is imperfect according to the mensuration to make the note perfect, that is to increase the note's value by half, similar to our dot. The p.d. serves to separate one note from the other, usually to prevent the alteration or imperfection of an adjacent note. The p.d. is put to use in syncopatio or syncopa, as illustrated by the anonymous author of the Ars cantus mensurabilis mensurata per modos iuris treatise, who writes:

In maiori prolatione multe syncope inveniuntur et varie, quamvis sint idem in substantia, et primo invenio in motetto Ida capillorum talem syncopam ut hic:

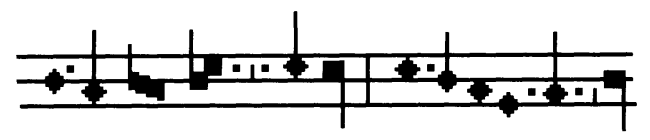

Illa prima minima reducitur cum illis duabus posterioribus, scilicet cum pausa minime et minima.

In conjunction with the definition given by this theorist that

\footnotetext{
${ }^{18}$ R. RASTALL, The Notation of Western Music (London 1983), p. 82.

${ }^{19}$ Blue notes are also found in the Old Hall MS, vid. W. APEL, The Notation of Polyphonic Music (900-1600) (Cambidge/Massachusetts 1953), pp. 405-434.

${ }^{20}$ E. DE COUSSEMAKER (ed.), Scriptorum de Musica medii aevi: novam seriem a Gerbertina alteram, 4 vols (Paris 1869) [hereafter cited as CS], III, pp. 213b. Jean de Muris calls the former the punctus augmentationis in his Ars Contrapunc$t i$, CS III, p. 92a.

${ }_{21}$ 'In major prolation many and varied syncopations are found, although they are the same in principle, and I first found this kind of syncopation in the motet Ida capillorum as here: ... That first minima is grouped together with those two later ones, namely with the minima pause and the minima.', C. M. BALENSUELA, Ars cantus mensurabilis mensurata per modos iuris = Greek and Latin Music Theory 10 (Lincoln 1994) [hereafter ArsM], p. 212.
} 
...sincopa est quo ad totum alicuius note mediante imperfecto vel divisio facta in modo, tempore, vel prolatione. Dixi imperfectio quo ad modum, tempus, vel prolationem perfectam; dixi divisio et hoc quo ad modum, tempus, vel prolationem imperfectam... ${ }^{22}$

we may understand that syncopa is the process whereby a perfection is divided into smaller values. ${ }^{23}$ By extension, the example given by this theorist shows that, by effectively protecting each division of a 'syncopated' perfection from adjacent notes, the p.d. allows these divisions to be interpolated by other notes or perfections. ${ }^{24}$ This device, which Willi Apel terms displacement syncopation, ${ }^{25}$ is first found in the late works of Machaut which suggests its development after circa 1360 within the French tradition.

In the sources of Senleches' works, this p.d. in conjunction with minima is avoided in favour of coloured minime. Its consistent use between sources and the close apposition in the MSS of those pieces avoiding the p.d. to those that do use it, suggests that the practice was particular to the composer and not the scribe, although it is evident that some pieces employ both methods, sometimes simultaneously. The practice arose out of the principle of minima equivalence in French music and, just as in the technique of employing the p.d., it occurred only in major prolation. With respect to Senleches, examples of this device can be found throughout En attendant. In the first system of this work, ${ }^{26}$ before the first pausa semibrevis, the following is found:

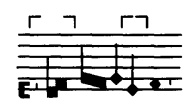

In this example, an imperfect semibrevis is divided into two minime, namely the initial red minima pausa and the last red minima. The last of the two minime cannot be altered before the final semibrevis because it is essentially a different figure to the preceding black minima. Elsewhere in the repertoire, one finds equivalent passages notated using the p.d., such as the following example from the refrain of the $S^{27}$ voice in the Mod version of the ballade En attendant soufrir m'estuet which is ascribed in that MS to Philipoctus de Caserta. ${ }^{28}$

\footnotetext{
${ }^{22}$ 'syncopa is made in modus, tempus or prolation whenever the whole of any note is split by imperfection or division. I have said imperfection whenever modus, tempus or prolation are perfect. I have said division and and this is whenever modus, tempus or prolation are imperfect', ArsM, p. 212.

${ }^{23}$ cf. W. FROBENIUS (ed.) Johannes Boens Musica und seine Konsonanzenlehre = Freiburger Schriften zur Musikwissenschaft II (Stuttgart 1971), p. 163.

${ }^{24}$ cf. APEL, Notation, pp. 395-402 \& 414-17.

${ }^{25}$ APEL, Notation, p. 414.

${ }^{26}$ Apel's facsimile of this work (Notation, p. 423) is incorrectly printed with the first minima rest black. In the manuscript, it is red.

${ }^{27}$ Abbreviations for vocal appellations used throughout this article are as follows: $\mathrm{S}=$ vox superius, $\mathrm{Ct}=\mathrm{Contrate}-$ nor, contreteneur, $\mathrm{T}=$ Tenor, teneur.

${ }^{28}$ Mod 34; cf S in first and third systems of Anthonellus de Caserta's Dame d'onour en qui, Mod \#81. A facsimile of that piece may be found in F. FANO, La Cappella musicale del Duomo di Milano (Milan 1956), Plate XVIII. The strongest support for the equivalence of both manners of notating using either coloured minime or the p.d. is found in the anonymous composition Sans joie avoir, which occurs in both $C h \# 23$ and Pit 45 . The $C h$ version contains many red minime and semibreves in a syncopated style. The Pit version of this work sees the red minime notated as black
} 


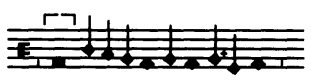

It can be suggested, on the basis of the previous example from En attendant esperance, that Senleches would have instead notated this passage with the minima pausa, the brevis and last minima all in red ink. As shown in the following example, Senleches plays on minima equivalence and the role of red minime in the passage subsequent to the previous example from his En attendant esperance where a sole black minima is found amongst a collection of red notes.

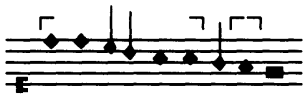

The black minima in this example remotely imperfects the next black brevis, thereby completing the perfection.

Further examples of Senleches' use of coloured minime and the avoidance of the p.d. occur in Je me merveil, whose only surviving version occurs in Ch. The void black notes in this piece assume minima equivalence and a sesquialtera proportion at the semibrevis level. Their behaviour is identical to that of the red notes in En attendant esperance. Red notes in Je me merveil instead presume brevis equivalence and result in augmentation at the minima level. The individual void black minime scattered throughout the stollen of $\mathrm{C} 1$ of this piece achieve a high degree of syncopation.

The consistent use of coloured minime to achieve syncopation in the collective transmissions of En attendant esperance and the presence of the same device in Je me merveil suggests that this device is a particularly idiosyncratic feature of the notational style of Senleches. The use of the device is obviously twofold: firstly to simplify notation by not employing the p.d. and secondly, emphasising the components of perfections to assist the performer. This device plainly relies on principles of French notation and operates within the bounds of the syncopated style first evident in the music of Machaut and his late contemporaries.

The simple void red forms found in En attendant, esperance confort provide an example of the new proportional usage of coloration to express richer rhythmic relationships. This piece illustrates the use of void red minime, semibreves and breves. ${ }^{29}$ There are obvious four-fold and two-fold groupings of these notes, and Apel was the first to suggest that these forms, respective to the full-black notes, represent a sesquitertia proportional relationship, that is $4: 3$ at the minima level

with the p.d., red semibreves as dragme and red breves as void black breves. The variance in Pit may be explained as the result of scribal avoidance of red ink, but it does show the equivocal nature of this two devices.

${ }^{29}$ This author's solution to the passage with void red breves can be seen in the transcription follow this article. The correct value of the void red breves is half a black brevis or a perfect semibrevis. The minima pausa (quaver rest in b. 36) serves to displace the melody one minima so that in b. 37 both $\mathrm{S}$ and $\mathrm{Ct}$ appear displaced correlatively with respect to the T. This minima pausa and the minima d in b. 39 imperfect the brevis in that bar, that is one imperfects remotely, the other directly. 
and dupla (2:1) at the semibrevis level. ${ }^{30}$ Ursula Günther ${ }^{31}$ provided valuable insight into this use of coloration in Codex Chantilly, looking especially at the sources and also briefly mentioning the theorists. ${ }^{32}$ Recently, Anna Maria Busse Berger has examined this device's origin and use, especially in relation to mensural signs in a wider range of pieces. ${ }^{33}$

An examination of the theorists will give this practice greater chronological weight. In his Expositiones tractatus practice cantus mensurabilis magister Johannes de Muris, written some thirty years after the practice had come into use, Prosdocimus de Beldemandis states:

Item quod non sint ponende octo rubee vacue <minime> pro sex nigris plenis aut quatuor pro tribus potest sic probari, quoniam aut vis quod rubee plene amittant terciam partem valorum ipsarum si evacuentur et quod nigre plene per evacuationem vel mutationem coloris nichil amittant de ipsarum valore sed solum assumant prolationem oppositam, aut vis quod tam rubee plene quam nigre plene per evacuationem aut per mutationem coloris assumant diminutionem tercie partis...Quidam tamen huius artis magister qui ad presens magister magistorum reputatur, volens manutenere hanc figurationem pro bona, dicit has figurationes in proportione cantari, ignorans quid loquatur de proportione, cum in rei veritate quicquid cantatur, in aliqua proportione cantatur. Et dicit ulterius quod tales figure cantantur in proportione sexquitercia <sic>, et dum huius causam quererem, nescivit michi reddere aliam causam quam: sic volo. ${ }^{34}$

In this passage reprimanding musicians for using such an illogical device, we read that the practice of singing void red minime in the sesquitertia proportion is perpetuated by an essentially oral tradition and without a strict mathematical

\footnotetext{
${ }^{30}$ APEL, Notation, p. 424.

${ }^{31}$ U. GÜNTHER, Die Anwendung der Diminution in der Handschrift Chantilly 1047, in: AfMw XVII (1960), pp. 1-21; IDEM, Der Gebrauch des tempus perfectum diminutum in der Handschrift Chantilly 1047, in: AfMw XVII (1960), pp 277-297. In the former article, Günther, in arguing that diminution was a French development of the ars subtilior, examines the methods by which diminution is notated in twenty-three works from Codex Chantilly. The most consistent usage is the void red form to denote a sesquitertia proportion at the minima level. Full red notation, aside from its usual meaning, is also used to achieve the same diminution and also a sesquialtera proportion at the minima level ( $\mathrm{Ch}$ 61). Other devices discussed include note caudate, mensural signs, combinations of mensural signs and coloration, the numerals 2 and 3 to denote duple and triple diminution respectively, and canons.

${ }^{32}$ GÜNTHER, Der Gebrauch des tempus, p. 297.

${ }^{33}$ A. M. BUSSE BERGER, The Origin and Early History of Proportion Signs in: JAMS 41 (1988), pp. 403-33. This article examines the historical development of the use of proportion signs. The use of mensuration signs alone or combined with coloured notes is viewed by Berger as an early stage in the development of proportional notation. The use of numerals and cifres represents the first steps to the cumulative proportional signs evident in the second half of the fifteenth century.

${ }^{34}$ 'Similarly, it is recommended that eight void-red minime should not be substituted for six full black minime or four (void-red minime) for three (full-black minime), since either full-red (minime) lose a third part of their value if hollowed out and full black (minime) by hollowing out or changing their colour lose nothing of their value but only assume the opposite prolation, or just as full-red (minime) so too do full-black (minime) assume a diminution of a third through hollowing out or through changing their colour...However, a certain master of this art, who at the present time is regarded as the master of masters, wishing to retain this figuration for good reasons, says that these figures are to be sung proportionally, ignoring what was said concerning the proportion (by the theorist), since anything actually sung is sung in another proportion. And the former says that such figures are to be sung in a $4: 3$ proportion, and while I might question the reason for this, I do not know any other reason for it other than: I will.'; F. A. GALlo (ed.), Prosdocimi de Beldimandi Opera: Expositiones tractatus practice cantus mensurabilis magister Johannes de Muris (Bologna 1966), LX.44-50 f.
} 
premise apparent to the theorist. The second Berkeley treatise of circa 1375 writes that void red notes can yield a sesquialtera proportion, ${ }^{35}$ however this is usually achieved in MSS of this period with an accompanying mensuration sign and/or canon. ${ }^{36}$ More telling is the previously mentioned Tractatulus de figuris et temporibus which contains the following passage:

Si volumus augmentare supra tempus inperfectum majoris prolationis in proportione sexquitercia, appone octo minimas vacuas pro tempore, ut hic: $161626{ }^{37}$

In the Ars cantus mensurabilis mensurata per modos iuris, in a chapter on red and void black notes and after explaining the traditional use of coloration, the author states that, although it is not technically correct (quod hoc non est bene positum), four red or void semibreves (or four dragme) can be placed for one tempus in tempus imperfectum cum prolationis maioris, and that four red or void minime can be placed for a prolation in the same mensuration. ${ }^{38}$

Examples of this red or void black sesquitertia coloration in the music of the time may be noted in the anonymous Laus detur (Ch 10), Suzoy's Pictagoras, Jabol et Orpheus (Ch 39) and the contratenor of Hymbert de Salinis' En la saison [Tenor: Jo. Cunelier] (Ch 72). ${ }^{39}$ Pieces using a mensural sign before the vacue or rubee forms to represent sesquitertia proportions are also common and perhaps represent a 'refinement' of the practice. ${ }^{40}$ The use of the void red form is obviously derived from the practice mentioned in both the Tractatulus and Ars cantus mensurabilis mensurata, ${ }^{41}$ and it is well represented in the ars subtilior repertoire, most notably in the anonymous Un crible plein (Ch 4), De tous les moys (Ch 76) and of

\footnotetext{
${ }^{35}$ Item sunt aliqui ponentes diversos colores in brevibus, semibrevibus, et minimis, et in unum illorum colorum diminuere volent, ponunt eum vacuum sic, videlicet ut sunt 3 rubee semibreves valent duas nigras, minimis nigris et rubeis eiusdam valoribus existentibus, ita 3 minime rubee vacue valebunt duas minimas plenes, semibrevibus ipsis rubeis tam plenis quam vacuis eiusdem valoris existentibus. ('Likewise the are some men writing different colours on breves, semibreves and minime, and wishing to diminish one of those colours, they write them hollow so that just as three red semibreves are worth two black <semibreves>, with the black and red minime having the same values, so too are three void red minime worth two full red minime, with both the red and void semibreves having the same value'), O. B. ELLSWORTH, The Berkeley Manuscript: University of California Music Library, MS. 744 (olim Phillipps 4450) = Greek and Latin Music Theory 2 (Lincoln and London 1984), p. 128-30.

${ }^{36}$ vid. BERGER, op. cit., pp. 407-409.

${ }^{37}$ 'If we wish to augment above imperfect time with major prolation in the 4:3 proportion, (it is done) by placing eight void minimas for (one) tempus, as here, etc.' Tractatulus, ch.1.6 in: GALLO, Mensurabilis Musicae Tractatuli. The infinitive augmentare is obviously used in a technical sense meaning to increase the number of minime. Prosdocimus also writes: ... quod moderni ponentes pro fractione sexquitercia notas rubeas plenas vel nigras vacuas, et hoc figuratione comunissima ut quatuor pro tribus vel octo pro sex, pessime ponunt; GALLO, Prosdocimi, etc., ch. LXI.35 ('but the moderns placing for the 4:3 proportion full-red note or black-hollw (notes), place most poorly in this very common figuration four for three (notes) or eight for six (notes).')

${ }^{38}$ ArsM, pp. 226-228. The opposite effect of subsesquitercia proportion using the same notation in minor prolation is also explained by this theorist, ibid., p. 228. CUNELIER's Lorsque Artus (Ch 61) employs red notes in this manner.

${ }^{39}$ GÜNTHER, Die Anwendung, pp. 14-17.

${ }^{40}$ BERGER, op. cit., p. 411, Table 4.

${ }^{41}$ Interestingly, Anne Stone has recently revealed that a passage of solid red notes, used to represent the sesquitertia proportion, was erased and replaced by void red notes in Anthonellus de Caserta's Amour m'a le cuer mis (Mod\#62), STONE, op.cit., pp. $111 \mathrm{f}$. This suggests that the scribe modified the passage from that which occurred in the older exemplar to suit his current notational tastes.
} 
course in En attendant esperance conforte..$^{42}$ Prosdocimus' admonishment of this practice unwittingly provides the best insight into its use and existence, while the writings of earlier theorists clearly establish a foundation for the practice that is mirrored in the surviving sources.

The presence of this void red coloration is a significant indication of the ars subtilior style through its redivision of tempus and prolation. Its use as, in En attendant, sees the tempus and prolation effectively divided four-fold, a division which is relatively new and outside the possibility of the notational system of the ars nova. However, the equivalent device was fully available in the octonaria division of trecento notation through the use of the Italian punctus divisionis. In light of Prosdocimus' statements, it is clear that this coloration served to remind the performer of an existing oral tradition. Although this notation is found in both major sources of the repertoire (Mod \& $C h$ ), the notation represents not an Italianisation of the French system, but the extension of the French device of coloration in order to satisfy the need to notate new rhythmic divisions. The fact that Prosdocimus discusses this particular notation in a commentary on a treatise by Johannes de Muris is also a significant indication of the French provenance of this notational device.

Senleches' La harpe de melodie also sees coloration used in conjunction with a canon $^{43}$ to indicate how particular coloured notes should be performed. The Newberry source (Chic) of this piece has a rondeau running down the right arm of the harp illustration, while the same rondeau appears below the music in $\mathrm{Ch}$. This rondeau is a canon which not only informs the performer how to add the second upper voice, but also specifies: Par blanc et noir per mi sans oblier / lay le tonant ou tu li feras tort ('Let the black and white notes sound by half without forgetting or you will do them wrong'). ${ }^{44}$ Observing this instruction results in the black figures in the upper voice being half the length of the red notes in the same voice and half the length of the black notes in the tenor. In the upper voice, aside from being diminished, the void white notes behave in the normal manner, providing a sesquialtera proportion with minima equivalence. Hence, in this piece, besides retaining their usual property of indicating the opposite mensuration,

\footnotetext{
${ }^{42}$ Other examples of this particular meaning of notation are found in the superius of the aforementioned En la saison, the anonymous Va, fortune (Ch 37), Philipoctus de Caserta's De ma dolore (Ch 42), Par le grant senz d'Adriane (Pit $185 \&$ Ch 54. Latter uses full red) and En remirant (Ch 57 only, Mod 67 uses mensuration signs instead), Cunelier's Se Gallas et puissant Artus (Ch 55), and Magister Zacharias' Sumite karissimi (Mod 15) cf. Table by GÜNTHER, Die Anwendung, pp. $12 \mathrm{f}$.

${ }^{43}$ The canon is quite common in pieces from this period. The Berkeley treatise contains the following passage which condones the use of this device: ...unde qualitercumque in subscriptionis habetur, ita est cantandum, eciam si fuerit contra artem. Nam communiter canones ponuntur quando commode taliter secundum artem non posset in cantu procedi, etsi posset tamen hoc latet. ('... whatsoever is contained in written instructions, must be sung accordingly, even if should be against art. For canons are commonly added when it is not wholly possible to proceed easily in a song according to art, [or] even if able [to proceed according to art], but the latter is obscure.'), ELLSWORTH, op.cit., p. 170-72. In Ch, there are at least seventeen pieces which utilise a canon in one form or another (Ch 2 [text], 8, 9, 26, 33, 34, 39, 46, 47, 53,55 [text], 58, 61, 63, 67, 71, 77 [text?]). There are no less than fourteen occurrences in Mod $(1,4,6,16,30,36,51$, $52,59,72,81,82$ [text], 101, 102).

${ }^{44}$ Translated by R. HopPIN, Anthology to Medieval Music (New York 1978), p. 171. Nors Josephson correctly interpreted the canon in his article, Die Konkordanzen zu "En nul estat" und "La harpe de melodie", in: Mf XXV (July-Sept. 1972), p. 299, fn. 13; cf. IDEM, Vier Beispiele der Ars Subtilior, in: AfMw XXVII (1970), pp. 45-47.
} 
red notes are used as signifiers to which the canon can be applied. Jean Haspre's Puis que je sui fumeux (Ch 47) contains a similar device whereby the performer is instructed to sing the red notes in proporcione dupla. Although not identical to this usage, several pieces from the repertoire use mensural signs as signposts to which their accompanying canon refers. ${ }^{45}$

One final form of coloration apparent in the composition Je me merveil involves simple figures which are half black and half red or void. These particular forms are referred to as particoloured figures in reference to the festive style of medieval livery. The duration of these particolours may be reckoned as the value of a figure in the colour of the first half of the note imperfected or augmented by half the value it would lose or gain through full coloration. ${ }^{46}$ Therefore, the term 'half-coloration' can also be used to describe these note forms. Alternatively, their value can calculated by the addition of half the value of the equivalent red or void figure and half the value of the equivalent black figure. However, the former approach appears to be that most concurrent with theoretical thought during this period. Clearly, the value of these forms is dependant on the mensuration in which they occur.

While the particoloured brevis occurs frequently in the Modena manuscript, the particoloured semibrevis is found only in Codex Chantilly in Senleches' Je me merveil and Rodericus' Angelorum psalat. In both cases it has the value of twoand-a-half minime. Once again, this device represents an attempt to broaden and refine ars nova notation. Whilst such values could be expressed by imperfection, the very independence of the particoloured figures to those adjacent to it, supplies the freedom for the bold rhythmic experiments evidenced by Je me merveil.

\section{The figure caudate.}

Figure caudate ('tailed notes') occur in three pieces from Senleches' repertoire, namely La harpe de melodie, En attendant esperance conforte and Tel me voit. These forms are distinguished especially by the addition of tails below a note, rather than the more usual form of tails above the note as in the case of minime, although some forms function through the addition of tails both above and below the note.

While certain signs can be attributed to the deliberate avoidance of the semiminima by composers of a mainly French background, ${ }^{47}$ many signs must be

\footnotetext{
${ }^{45}$ These pieces are Galiot's Le sault perilleux (Ch 53), Haspre's Puis je sui fumeux (Ch 47), Golscalch's En nul etat (Ch 58), M. de Sancte Johanne's Je chante ung chante (Ch 9), Johannes de Alte Curie Se doit il plus (Ch 8), Johannes de Janua Une dame requis (Mod 16). In her discussion concerning Le sault perilleux, Günther's etymological analysis of the term epogdoa is erroneous in that she maintains that the word is derived from $\dot{\varepsilon} \pi \dot{i}+$ ok $\tau \dot{\omega}$, which would indicate the proportion 9:1 (lit. 'one and eight'), in: Der Gebrauch des tempus..., p. 294. The correct etymological construction is $\dot{\varepsilon} \pi i+\ddot{0} \gamma \delta 00 \zeta$, which denotes the proportion of 9:8 (lit. 'one and an eighth').

${ }^{46}$ cf. J. HIRSHBERG, The Music of the Late Fourteenth Century: A Study in Style (Ph.D. University of Pennsylvannia 1971), p. 324. Hirshberg believes that all figures are augmented, but he fails to take into account the fact that the first half of the particoloured note determines the effect of the second half.

${ }^{47}$ The scholastic maxim of the fourteenth century 'non est minimo dare minor' is often the argument found in theorists for the avoidance of the semiminima. cf. H. UlRICH (ed.), Johannes de Muris Notitia artis musicae et Compendi-
} 
attributed to the scribe, or possibly the composer, seeking to represent unequivocal, discrete values in the music, often representing proportional relationships in a way not encountered prior to this period. For example, noting that En attendant esperance can be determined to be in tempus imperfectum cum prolationis maioris, ${ }^{48}$ the caudata seorsum et deorsum retorta dextra shown as Figure 4 in Table 2 (s. p. 150) appears to represent one sixth of a perfect semibrevis. This value can be deduced by considering the groups of six of these notes in the sections corresponding to the ballade's fourth line and refrain, which without doubt must be construed within the space of a perfect semibrevis. This was first observed by Apel in his transcription of Mod and was also adopted by Greene in his edition of $\mathrm{Ch}^{49}$ While this value could theoretically be represented by the semiminima, it appears that many French musicians did not employ the theoretical semiminima possibly due to its uncertain nature.

One is tempted to proffer the Ars nova of Philippe de Vitry as the treatise with the earliest definition of the semiminima with a dating of circa 1320 . However, present scholarship has shed sufficient light upon the uncertain transmission of the disparate set of writings which modern editors have used to form critical editions of the supposed Ars nova treatise so that it is very difficult to say whether the semiminima was codified by de Vitry at all. ${ }^{50}$ Furthermore, the form is not mentioned by de Vitry's contemporary and fellow advocate of the new art Johannes de Muris. ${ }^{51}$ However, it becomes apparent that the semiminima was already in use in the second decade of the fourteenth century as it is drawn ()$^{52}$ and defined as half a minima ${ }^{53}$ by Jacques de Liège in his attack on the new art in the seventh book of his Speculum Musicae. The earliest extant musical source using a semiminima form $\mathcal{f}^{2}$ is the Italian Codex Rossi. ${ }^{54}$ However, in recent years, this manuscript's date has been moved considerably forward into the last half of the fourteenth century to undermine its significance..$^{55}$ On the other hand, the sources of Guillaume de Machaut, all after 1349, never employ the semiminima. Contrary to views such as those given by Cecily Sweeney in the introduction to CSM $13,{ }^{56}$ it is therefore reasonable to suppose that the

um musicae practicae. = Corpus Scriptorum de Musica [hereafter CSM] 17 (Rome 1972), p. 102; R. BRAGARD (ed.), Jacobi Leodiensis Speculum Musicae. = CSM 3, 7 vol. (s.l., 1955-1973), vol. 7, ch 7, sent. 35.

${ }^{48}$ The mensuration of pieces is determined using trial and error and the methods in: APEL, Notation, pp..346 f.

${ }^{49}$ APEL, French Secular Music, p. 167-169; G. K. GREENE, French Secular Music: Manuscript Chantilly Musée Condé 564, Second Part. $=$ Polyphonic Music of the Fourteenth Century XIX (Monaco 1982), pp. 58-61.

${ }^{50}$ vid. S. Fuller, A Phantom Treatise of the Fourteenth Century? The Ars Nova, in: Journal of Musicology IV (1985-86), pp. 23-50.

vid. U. Michels, op.cit. Prosdocimus de Beldemandis in his Expositiones on De Muris' treatise comments on the absence of the semiminima in Johannes' treatise, vid. F. A. GALLO, Prosdocimi, chap. 2, sent. 55-75.

${ }^{52}$ BRAGARD, op.cit., vol. 7, ch. XXIIII, sent. 11.

${ }^{53}$ BRAGRAD, op.cit., vol. 7, ch. XXXIIII, sent. 25.

${ }^{54}$ Rome, Biblioteca Apostolica Vaticana Rossiano 215 \& Ostiglia, Fondazione Opera Pia don Giuseppe Greggiati, fragmenti. Published in colour facsimile as N. PIRROTTA (ed.), Il Codice Rossi 215. = Ars Nova 2 (Lucca 1992).

${ }^{55}$ This is demonstrated by Nino Pirrotta's change of opinion where he revised his earlier dating of 1328-1337, in his Marchettus de Padua and the Italian Ars Nova, in: MD IX (1955), p. 67, to circa 1370 in his Chronologia e denominazione dell' Ars nova italiana, in: Les Colloque de Wegimont 2 (Paris 1959), p. 98. cf. PIRROTTA, Il Codice Rossi 215, p. 71.

${ }^{56}$ C. SWEENEY, Anonymus de Musica Mensurabili. = CSM 13 (s.l., 1971), pp. 17-20. 
semiminima was an experimental stage and not universally adopted throughout most of the fourteenth century.

The Berkeley Anonymous 2 treatise (1375) gives the semiminima in the form shown as the first form in Figure 1 in Table 1 (s. p. 149) or, as an alternative, the second form shown in the same table cell. ${ }^{57}$ The same treatise also gives the form shown as Figure 2 (first form) in Table 1, which is termed the addita and is equal to three-quarters of a minima, therefore representing a sesquitertia or 4:3 proportional relationship. ${ }^{58}$ The Tractatus Figurarum represents the semiminima as a void black form (see Figure 3, Table 1), ${ }^{59}$ whilst the value of the full black form is equivalent to the addita already described. ${ }^{60}$ The Tractatus de figuris et temporibus agrees with the Tractatus figurarum, although it does not name the void form, and calls the addita the semiminima. ${ }^{61}$

The ambiguity of the semiminima form is also reflected in the Codex Chantilly, whose compositions are by mainly French composers. Table 2 represents a summary of special figures found in Ch. Note especially figures 2, 8, 10, 11, 14 and 15. The multiplicity of these various figures representing the same value of half a minima again suggests through the sources that the semiminima was by no means an established form in the late fourteenth century. It also suggests that the form encountered in En attendant and those found elsewhere in the repertoire were felt to be more discrete than the semiminima. The variation of form is indicative of notational styles which at this time were by no means uniform with various pieces in $C h$, for example, representing divergent traditions.

The case is reversed when we approach a source consisting of the works of mainly Italian composers. Table 3 (s. p. 151) represents a summary of various special figures found in Mod. As can be seen, there are fewer alternative figures used to represent the value of the semiminima. This may be due solely to the Italians preferring the actual full black semiminima form with the meaning first advocated pseudo-de Vitry and Berkeley treatises. While the great number of works by de Perusio in this manuscript skews this result, the works of Anthonellus de Caserta, Bartholomeus de Bononia, Magister Zaccharias and other Italian composers demonstrate the use of the simple semiminima. However, the role of the scribe in this manuscript is an active one, and the modification and adaptation of notation is not only possible but also in evidence. ${ }^{62}$

\footnotetext{
${ }^{57}$ ELLSWORTH, op.cit., p. 126.12-15.

${ }^{58}$ ELLSWORTH, op.cit., p. 124.3-12.

${ }^{59}$ ELLSWORTH, op.cit., p. 82.4 .

${ }^{60}$ ELLSWORTH, op.cit., p. 84.11-14.

${ }^{61}$ Anonymus, Tractatulus, 3b.21, in: GALlo, Mensurabilis Musicae Tractatuli.

${ }^{62}$ Philipoctus de Caserta's En remirant (Mod 67) provides a clear example of the notational preferences of the Mod scribes. A pair of semiminime is found in the third system of this work. However, concordances $P R 172$ and $C h 57$ respectively use a pair of void red minime and void red dragme. cf. GÜNTHER, Die Anwendung, p. 17.
} 
Table 1: Special figures encountered in French and Italian Theoretical treatises of the Late fourteenth- and early fifteenth-centuries. ${ }^{63}$

\begin{tabular}{|c|c|c|c|c|}
\hline Figures & Value in & Name & Sources & Comments \\
\hline & $1 / 2$ & semiminima & $\begin{array}{l}\text { BA2, 126.13-15; TPMI, 229a; Ars D, } \\
\text { 76a \& 80a; SC, p. 72; A. de Leno, } \\
\text { 34. }\end{array}$ & $\begin{array}{l}\text { Leno: proportio dupla }(2: 1) \text { in } \\
{[2,3]}\end{array}$ \\
\hline & $3 / 4$ & $\begin{array}{l}\text { addita (BA2); } \\
\text { minima } \\
\text { imperfecta (TF); } \\
\text { semiminima } \\
(\text { Anon } X)\end{array}$ & $\begin{array}{l}\text { BA2, 124.3-6; Anon X, } 413 \mathrm{~b} \text {; Th. de } \\
\text { Campo, 185a; TF: } 84.11-14 ;\end{array}$ & $\begin{array}{l}\text { Anon } X \& \text { Theo. de Campo: } \\
\text { major prolation }\end{array}$ \\
\hline & $1 / 2$ & semiminima & ArsM, p. 248; TF 82.4f; tFT 3b.20; & $\mathrm{tFT}:[2,2]$ \\
\hline & $1 \frac{1}{2}$ & $\begin{array}{l}\text { fusa, minima } \\
\text { caudata sursum } \\
\text { et deorsum } \\
\text { (Anon X). }\end{array}$ & $\begin{array}{l}\text { BA2, 126.16-18; ArsM, p. 224; A. de } \\
\text { Leno, 31. Anon X, 414a. }\end{array}$ & $\begin{array}{l}\text { BA2: major prolation; ArsM: } \\
\text { [2, 3]; Leno: ex. major } \\
\text { prolation; Anon } X:[2,3]\end{array}$ \\
\hline & $1 \frac{1}{3}$ & (fusa) & $\begin{array}{l}\text { BA2, } 126.18-21 \text {; TF } 84.6 f(\text { vacua); } \\
\text { tFT 3b.19 (vacua) }\end{array}$ & TF: minor prolation; tFT: $[2,2]$ \\
\hline & 2 & $\begin{array}{l}\text { dragma or } \\
\text { (fusa); fuises } \\
\text { (BN lat. 15128) }\end{array}$ & $\begin{array}{l}\text { ArsM, p. 224; TF } 84.4 f ; \text { SC p. } 76 \text {; } \\
\text { ArsD, CS III, 107a; BN lat. } 15128 \text {, } \\
\text { p. } 88 .\end{array}$ & $\begin{array}{l}\text { ArsM: }[2,3] ; \text { TF: major } \\
\text { prolation; } \mathrm{SC}:[2,3]\end{array}$ \\
\hline & $3 / 4$ & (fusa) & $\begin{array}{l}\text { ArsM, p. } 226 \text { (cf. Anon V, CS III, } \\
\text { 394a) }\end{array}$ & $\begin{array}{l}\text { ArsM: “cum sit minoris } \\
\text { valoris” }\end{array}$ \\
\hline 8. & $\begin{array}{l}3 / 4,1 / 2,2 / 3 \\
4 / 3\end{array}$ & $\begin{array}{l}\text { minima vacua, } \\
\text { minima } \\
\text { imperfecta }\end{array}$ & $\begin{array}{l}\text { ArsM. p. 228; TF 88.6f; tFT 3a.6, } \\
\text { 3a.3, 3a.4; SC p.73; A. de Leno, 35; }\end{array}$ & $\begin{array}{l}\text { ArsM: } 3 / 4, \text { major prolation, } \\
4 / 3-[2,2] \text { (augment.); TF: } 2 / 3, \\
\text { minor prolation; } \mathrm{FFT}^{3} / 4-[2,3] \\
1 / 2-[3.3], 2 / 3-[3,2] ; \text { Leno: } \\
\text { dupla super biciens }(8: 3) \text {. }\end{array}$ \\
\hline & $\begin{array}{l}1 / 2(\text { Anon } X) \\
1 / 3 \text { (Leno) }\end{array}$ & $\begin{array}{l}\text { minima } \\
\text { semiminarum } \\
(\text { Anon } X)\end{array}$ & $\begin{array}{l}\text { Anon X, CS III, 414a; A. De Leno, } \\
\text { 36; }\end{array}$ & $\begin{array}{l}\text { Anon } X: \text { major prolation; Leno: } \\
\text { major prolation, proportione } \\
\text { tripla }\end{array}$ \\
\hline & $2 / 3$ & semiminima & TPMI, CS III, 229a; & \\
\hline & $1 / 4$ & & A. de Leno, 37; & $\begin{array}{l}\text { Leno: major prolation, } \\
\text { proportio quadrupla; }\end{array}$ \\
\hline & $3 / 4$ & & A. de Leno, 32; & $\begin{array}{l}\text { Leno: major prolation, } \\
4: 3\end{array}$ \\
\hline 13.$\}$ & $2,(3,5,6)$ & & $\begin{array}{l}\text { A. de Leno, 31; ArsD, 107a; (BN } \\
\text { lat. 15128, pp. 89-91); }\end{array}$ & $\begin{array}{l}\text { Leno, BN lat. 15128: major } \\
\text { prolation; }\end{array}$ \\
\hline
\end{tabular}

\footnotetext{
${ }^{63}$ The key to abbreviations used in Table 1 are as follows: CS III: COUSSEMAKER, op.cit.; vol. 3; Anon V: Anonymous V in: CS III; Anon X: Anonymous X in: CS III; A. de Leno: A. SEAY (ed.), Antonio de Leno: Regulae de Contrapunto. =Colorado Press Critical Texts 1 (Colorado Springs, 1977); ArsD = Johannes de Muris, Ars discantus in: CS III; ArsM = C. M. BALENSUELA, op.cit ; BA2 = EllswORTH, op.cit.; SC = A. GILlES \& C. SWEENEY (eds), Anonymus: De Semibrevis Caudatis. = CSM 13 (s.l., 1971), TMPI: Prosdocimus de Beldemandis, Tractatus practice de musica mensurabili ad modum Ytalicorum, in: CS III; Th. de Campo: (Pseudo-)Theodoricus de Campo, De musica mensurabili in: CS III; TF = SCHREUR, op.cit; tFT = GALLO, Mensurabilis Musicae Tractatuli.
} 
Table 2: Special Figures found in The Secular Music of Codex Chantilly.

\begin{tabular}{|c|c|c|}
\hline Figures & Value (in $\downarrow$ ) & Comments \\
\hline 1. $\vartheta$ & $67: 2 / 3$ & $67:[2,3](d . d)$ \\
\hline 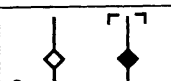 & $57: 1 / 2 ; 25,67: 11 / 3 ; 77: 2 / 3$ & $\begin{array}{l}25:[3,2], \text { red form after } \bigcirc, 3 x ; 57:[3,3] ; 67: \\
{[2,3] ; 77:[2,3] .}\end{array}$ \\
\hline 3. 1 & $\begin{array}{l}10,19,25,45,48,50,58,60,67,77: 11 / 2 ; 27 \\
28: 1 ; 41: 3 ; 57: 9 / 4 ; 64,77,100: 3 / 4 ; 50: 11 / 3 \\
56: 2 / 3 ; 42,92: 2 ;\end{array}$ & $\begin{array}{l}\text { 25: after } \bigcup_{[;} ; 6:[2,3] ; 10,19,42,50,58,92,100: \\
{[2,3] ; 27:[2,3] \text { only with form } 11,25,41,48,50,} \\
56,64:[3,2] ; 45,50,60,57:[3,3] ; 77:[2,3],[2,3] \\
\text { but red with black coloration; } 41:[2,2] ;\end{array}$ \\
\hline 4. & $68: 1 / 2$ & $68:[2,3]$ \\
\hline 5. $\}$ & $68: 2 / 3 ?$ & $68:[2,3] ;$ \\
\hline 6. 1 & $\begin{array}{l}25,58: 3 ; 28: 4 ; 56: 4 / 3,11 / 2 ; 57: 9 / 4 ; 67: 2 ; 77: \\
41 / 2 ; 100: 11 / 2 ; 50: 11 / 2 \text { or } 3 ;\end{array}$ & $\begin{array}{l}\text { 25: after } 2 ; 56:[2,2] ; 57:[3,3],[2,3], \text { groups of } \\
4 ; 67:[2,3] ; 28,100:[2,3] ; 77:[2,3] .50:[3,2]\end{array}$ \\
\hline 7. 2 & $64: 1 \frac{1}{2}$ & 64: $[3,2]$ \\
\hline 8. $\&$ or $\downarrow$ & $7,60,93: 1 / 2 ; 65: 3 / 4 ;$ & $60:[3,3] ; 7,65,93:[2,3] ;$ \\
\hline 9. & $35: 1 / 3 ; 65: 3 / 8$ & $35:[2,2] ; 65:[2,3]$ \\
\hline & $27,28: 1 / 2 ; 77: 3 / 4$ & $\begin{array}{l}27,28:[2,3], \text { only ever paired with fusa, } \\
\text { implying a three-fold division; } 77:[2,3] \text {. }\end{array}$ \\
\hline & $27,28: 1 / 2 ;$ & 27, 28: $[2,3]$; Always in pairs. \\
\hline & $77: 1 / 3(3: 2)$ or $5 / 16 ?(8: 5)$ & $77:[2,3]$. \\
\hline & 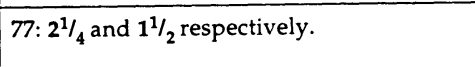 & $77:[2,3]$. \\
\hline 14. $b_{\text {or }}^{r} f^{\top}$ & $42: 1 / 2$ & $42:[2,3] ;$ \\
\hline 15. $\downarrow_{\text {or }}^{\Gamma} \oint^{\top}$ & 54 (red), $55: 1 / 2 ; 71: 3 / 4 ;$ & $54,55:[2,3]$ \\
\hline 16. & $60: 3 / 4$ & $60:[3,3]$ \\
\hline
\end{tabular}


Table 3: Special Figures in French and Latin Texted Music of Modena, Biblioteca estense, ms alpha.5.24.

\begin{tabular}{|c|c|c|}
\hline Figures & Value (in $\downarrow$ ) & Comments \\
\hline 1. & $13,38,45,61,64,74,84,86,89: 1^{1 / 2}$ & $13:[2,3],[3,2] ; 64:[2,3] ;$ minima + semiminima \\
\hline $2 .{ }^{7}$ & 61: 1 & $\begin{array}{l}\text { 61: [2,2], red; imperfect minima + imperfect } \\
\text { semiminima }\end{array}$ \\
\hline 3. & $\begin{array}{l}13,18,26,33,38,62,65,74,79,81: 11 / 2 ; \\
59: 2 / 9 ; 81: 11 / 3\end{array}$ & $\begin{array}{l}\text { 13, 18, 74: }[2,3] ; 26,33(\mathrm{dim}), 62,65(\mathrm{dim}), 79,81 \\
:[3,2] ; 59,81:[2,2]\end{array}$ \\
\hline 4.9 & $42: 4 / 3 ; 47: 1 / 2 ; 64: 3 / 4$ & $64,47:[2,3], 4: 3 ; 42:[2,2] ;$ \\
\hline 5.9 & $42: 2 / 3 ; 64: 1^{1 / 2}$ & $64:[2,3] ; 42:[2,2]$ \\
\hline 6. $f$ & $25: 2^{1 / 2} ; 64: 3^{1 / 2}$ & $64:[2,3] ;$ semibrevis + semiminima \\
\hline 7. 7 & $33,67: 3 / 4 ; 81: 1^{1} / 3 ;$ & $67:[3,3], 4: 3 ; 81:[2,2] \operatorname{dim}, 3: 2 ; 33:[3,2]$ \\
\hline 8.9 & $33: 2 ; 35,65: 3 ; 67: 9 / 4$ & 33: $[2,3] ; 35,65:[3,2]$ dim.; $67:[3,3] ;$ \\
\hline 9. & 72: $1 \frac{1}{2}$ & 72: $[3,2]$; \\
\hline 10. $\hat{Y}$ or $\bar{\gamma}$ & $72,79: 1 \frac{1}{3}$ & $72,79:[3,2]$ \\
\hline 11. $\phi \& \&$ & $96,101: 1^{2} / 3^{\prime}$ & $\begin{array}{l}\text { 96: [3,2]; 101:[2,3]; (N.B. red ink in these figures } \\
\text { is here represented by gray.) }\end{array}$ \\
\hline 12. $\stackrel{l}{<}$ & $13: 1 / 3$ & 13: $[2,3]$; half imperfect semiminima \\
\hline 13. ${ }^{r}{ }^{\top}$ & 101: $1 / 6$ & 101: $[2,3]$ \\
\hline $14 . \oint$ & $13: 1 \frac{1}{6}$ & 13: $[2,3]$ \\
\hline 15. $\downarrow$. & 13: $1 \frac{1}{2}$ & 13: p.d. differentiated by form \& context. \\
\hline 16. $\oint$ & $78: 5 / 6$ & $78:[2,3]$ \\
\hline 17. \{ & $78: 1 / 2$ & 78: $[2,3]$ \\
\hline 18. & $42: 1^{2} / 3($ minima + figure 4$)$ & 42: $[2,2]$; \\
\hline
\end{tabular}


Returning to the double tailed figures in En attendant esperance, it is necessary to explain the methods used during this period to create new note values. There are four apparent methods employed for creating new note values not found in the mainstream ars nova and trecento traditions. ${ }^{64}$ This was an experimental and flexible stage in notation, with composers and scribes creating new forms by applying established principles. The process is comparable to the creation of new values in traditional modern notation by the addition of the dot, proportional brackets or ties. The mechanisms which the musicians and scribes of the ars subtilior used may not have been so universal as our systems, but an analysis of them may help to contribute to understanding the logic behind these special figures. Apart from coloration, the methods apparent in the period for altering note values are the use of a stem to reduce or augment a note, the use of composite figures and the use of stems and tails (virgule) to represent proportional relationships.

Prosdocimus quite explicitly refers to a practice of creating new forms using the tail or stem to express new rhythmic durations when he writes:

Possumus etiam per appositionem caudarum extraneas figuras fabricare, hoc est extraneorum valorum, et hoc bene et cum rationibus satis evidentibus... ${ }^{65}$

In a passage describing the logic behind the value of the Figures 4 and 5 of Table 1 , which its author terms a fusa, the second Berkeley Anonymous treatise states that:

Nam sicut cauda sursum alleviat aliquando pro medietate, sic cauda deorsum tendens debet pro medietate per oppositum aggravari, si sursum tollat per oppositum deorsum debet augere. ${ }^{6}$

Using this principle, the theorist then explains why the fusa or dragma should be worth one-and-a-half minime, adding that the downward tail can also add a third of the value to the figure. ${ }^{67}$ Looking at theoretical values Figures 4 and $5 \mathrm{a}$ in Table 1 fit neatly into this category and Figures 2, 3 and 6 in Table 2 also corre-

\footnotetext{
${ }^{64}$ One further device that is used frequently is the previously mentioned punctus additionis or punctus perfectionis. Its application to a semiminima as in Figure 16 of Table 2 is very rare, and is influenced more so by Italian practice than French, as shown by Table 3, Figure 15 which occurs in a piece by Matheus de Perusio. This device, however, is not included in the present discussion since the form holds no implications for the examination of figure caudate.

${ }^{65}$ 'We are also able by the application of tails to make unusual note forms, that is of unusual durations, and this is good and satisfactory in its evident rationality...', GALLO, Prosdocimi, p. 145 (LXI.52).

${ }^{66}$ 'For just as a stem above (a note) sometimes lightens by a half, so too a stem hanging below (a note) ought to do the opposite and make it heavier by a half: if above it reduces, below, in the opposite manner, it ought to increase'; ELLSWORTH, op. cit., pp. 126.21-128.2.

${ }^{67}$ Prosdocimus also writes: Sed cum cauda superius tracta et cauda inferius tracta sint opposita et cauda superius tracta habeat diminuere, ut patere bene consideranti, sequitur quod cauda inferius tracta hebeat suum oppositum operari, scilicet augmentare... ('But since the tail drawn above [a note] and a tail drawn below are opposite and the tail drawn above has to diminish, it follows that the tail drawn below has to operate as its opposite, namely to augment...'), GaLlo, Prosdocimi, p. 146 (LXI.55).
} 
spond. It is important to note, however, that these values may be derived through other methods set out below.

Composite figures, which represent the second practice, occur in the music of Italian composers in both the late trecento, for example double tailed forms in Paolo Tenorista de Florentia's Amor da po che tu ti maravigli (Pit 109), and in the ars subtilior (although quite late), especially in the music of Matheus de Perusio. Examples occur in Matheus' pieces Trover ne puis (Mod 94), his Helas merci (Mod 76) and Le graynour bien (Mod 61). The forms in music with an obvious Italian origin include many smaller, caudate forms (s. Table 3). ${ }^{68}$ The treatise which clearly outlines these principles is the previously mentioned Tractatus figurarum, although only one figure developed in this treatise is patently evident in any surviving MSS. ${ }^{69}$ However, the logic Tractatus figurarum uses to determine the new figures can be applied to other figures in the repertoire. The result of this approach to notation in the Tractatus is that it tends to remove the dependence on context which governs the simple figures in French music through the use of figures composed of a minima and a smaller duration. ${ }^{70}$ In practice, as apparent from the figures in Table 3, the stem for the smaller value is placed below the note, as in the Tractatus, but it is frequently drawn as if the note as a whole had been rotated 180 degrees.

The third practice involves especially the use of the downward stem to imply either a subsesquialtera (2:3), ${ }^{71}$ a sesquialtera (3:2), ${ }^{72}$ or sesquitercia (4:3) proportion depending on the mensuration of the piece. ${ }^{73}$ Antonio de Leno, as shown in Table 1, figure 11, implies its usage by the addition of a downwards tail to a semiminima form to obtain a three-fold division of the minima, creating a major rather than the usual minor subprolation. Perhaps this was viewed as a logical extension of the property of an upwards tail which caused a two- or three-fold division of the semibrevis. The effect of the tail is dependent on the tempus and prolatio in use. Thus it is logical to find four dragme in the place of a brevis in [2,3] or $[3,2]$, three in the place of $[2,2]$ or 4 or 8 in the place of $[3,3]$, since the intention

\footnotetext{
${ }^{68}$ vid. APEL, French Secular Music, p. 8 a.

${ }^{69}$ The figure shown in Table 3, Figure 9 occurs in the CT of Bartholomeus de Bononia's Que pena maior agitanda (Mod \#72). This figure and its value is explicitly given by the author of the Tractatus Figurarum, SCHREUR, op.cit., p. 88.3; The figure is incorrectly printed in the diplomatic facsimile by Wolf as a hollow form, J. WoLF, Geschichte der Mensural-Notation von 1250-1460, 2 vol. (Leipzig 1904; repr. Hildesheim 1965), II, p. 124; APEL, Notation, p. 430 gives the correct form but Greene perpetuates this error in his critical notes to this piece in French Secular Music: Virelais. = Polyphonic Music of the Fourteenth Century XXI (Monaco 1987), p. 167.

${ }^{70}$ W. ARLT, Der Tractatus Figurarum - ein Beitrag zur Musiklehre der "ars subtilior", in: Schweizer Beiträge zur Musikwissenschaft I (1972), p. 53.

${ }^{71}$ e.g. superius in Anthonellus de Caserta's Du val prilleus (PR 92) in [2,3]. The passage is notated proportionally with the value of the dragma being relative only to its own line; q.v. tenor in the same composer's Dame d'onour en qui (Mod 81) (Facsimile in F. FANO, op.cit., Table 18.): the passage is actually the mensuration [3,2] in proportio dupla, each dragma equal to one-and-a-half imperfect semibreves, i.e. 1:3 at the minima level; q.v. Anon., Je ne puis avoir plaisir (Ch 25, Mod 35).

${ }^{72}$ Anthonellus de Caserta, Dame d'onour en qui (Mod 81) in $[2,2]$ but uses red coloration in $S$ in direct horizontal apposition to black dragme in $[3,2]$ in $\mathrm{Ct}$.

${ }_{73}$ e.g. Anon, Je la remire sans mensure (Mod 65, Pit 186, PR 171) at semibrevis level, [3,2]; cf. Philipoctus de Caserta's Par les bons gedeons (Mod 59) (Diplomatic copy in WOLF, op. cit., n.LXVI), at the semibrevis level in [3,3]; for 4:3 proportion at the minima level, q.v, Philipoctus de Caserta's En remirant (Mod 59). Red ink is used to clarify the relationship.
} 
in the music is to create an apparent inverse proportionality thereby effectively shifting the music to another mensuration. Coloration of these figures appears to be a device for indicating diminution (that is, in terms of ratios, where the left side is greater than the right) or for reinforcing the tripartite division. The resultant ratios always consist of one side divisible by three and the other by two, which may be construed to be a logical extension of ars nova theory. ${ }^{74}$

De Leno's Italian vernacular treatise raises certain issues for the historian of notation. Antonio's examples are clearly in the late trecento style of notation which has adopted all principles of French notation, but also includes a mixture of essentially Italian forms. However, whilst principles might be observed in his extraneous note forms, none are replicated in the music of Senleches apart from the similarities of sesquitertia division of the perfection by void minime and the subsesquialtera division by dragme. The problem we are faced with when encountering this mixed notation, ${ }^{75}$ is determining its origin of forms.

Having explained these devices, the problem of their application to the figures found in Senleches' works remains to be addressed. The note caudate in En attendant esperance, La harpe de melodie and Tel me voit must be interpreted using an extension of the principles of the third practice of adding stems to indicate proportional relationships. Indeed, as close inspection of Tables 2 and 3 shows, the majority of dragme and semibreves caudate in pieces from the repertoire can be explained using this principle. By extension, the virgula, a small tail curving to the left or right also indicates proportional relationships. The virgula curved to the right indicates a ternary division of the next mensural value, which may be seen as an analogy to the use of triplet figures. ${ }^{76}$ In the $C h$ version of En attendant, the form as shown as Figure 4 in Table 2 represents a ternary division of the void red semibrevis. Essentially it indicates a shift in prolation from minor to major but in a proportional manner. While it is arguable that this figure's value could be obtained through the use of a semiminima, the subtle distinction lies in the grouping of these figures not in pairs but in groups of three, with the binary division of the prolation by hollow red semibreves never being obscured.

Likewise in Ch, La harpe de melodie employs Figure 1 in Table 2 in the same manner to give the value of two-thirds of a minima. The prolation in that piece is major, but the void black notes represent the imperfection of the full-black semibrevis and the shift to a minor prolation with minima equivalence. The ternary division of an imperfect semibrevis, worth two minime, gives the previously mentioned value. Looking again at Rodericus' Angelorum psallat and the authoritative transcription by Nors Josephson, ${ }^{77}$ we find only notes with virgule turned to the left, as illustrated by figures $12^{78}$ and 13 in Table 2 . By analogy with

\footnotetext{
${ }^{74}$ cf. HIRSHBERG, op.cit., p. 319.

${ }^{75}$ This is the term used by APEL, Notation, p. 385.

${ }^{76}$ cf. HIRSHBERG, op.cit., p. 314.

${ }^{77}$ N. JOSEPHSON, Rodericus, Angelorum psallat, in: Mus. Disc. XXV (1971), pp. 113-126.

${ }^{78}$ At present, Figure 12 in Table 2 remains enigmatic, since its value remains ambiguous in Josephson's transcription of Angelorum psallat.
} 
the devices already present in the notational system such as coloration, this virgula appears to represent the opposite proportional relationship of 2:3. The forms shown in Figure 13 of Table 2 adhere to this system if we evaluate the black form as a four-fold division of a perfect brevis, the red form as an imperfect black form or as a fourfold division of the imperfect brevis.

While this virgula notation is not found outside these particular pieces from

$C h$, the parallel forms $\{$ or $\}$ and $\{$ encountered in the manuscripts Mod and Chic employ a flagged stem which achieves the same effect. The device is specific to only a small number of composers and evidently not just the practice of particular scribes as shown by the parallels between Mod and Chic. This use of the flagged stem corresponds to the logic of the aforementioned system described by Antonius de Leno. Apart from the forms in En attendant esperance and dragme occurring elsewhere the manuscript, many note caudate in the Modena manuscript can be explained as composite forms. While pieces by Matheus de Perusio account for most of these compound forms, the works of Zacharias (\#42), Bartholomeus de Bononia (\#72), Matheus de Sancto Johannes (\#25) and an anonymous author (\#45) also employ them.

The semibrevis caudata a parte inferior in La harpe de melodie is equivalent to two minime. While this is the value which at least two theorists attribute to this form (s. Figure 13, Table 1) inspection of its occurrences in Ch in Figure 6 of Table 2 reveals that in practice, its value greatly varies. However, in the music of Senleches, the figure operates consistently through the proportional properties of tails and represents a three-fold division of the imperfect, black brevis. Likewise, Senleches' Tel me voit uses a red form of this figure to divide the red (imperfect) brevis into three parts. In these examples, the downward tail divides the tempus contrary to its natural division, which implies that an imperfect tempus is divided perfectly, and vice versa. Bartholomeus de Bononia's Que maior pena agitanda (Mod 72) uses a hollow black caudata a parte inferior in a manner equivalent to the red caudata in Tel me voit. Therefore, with respect to the statement in the previous paragraph, it appears that at least two notational principles with regards to special figures are in operation throughout Mod 72. The semibrevis caudata and dragme in Tel me voit are used in a manner consistent to those values in La harpe de melodie and provides a connection between the two notational styles in these works.

The caudata a parte inferior appears to have an interesting history in the fourteenth century. Whilst it remained an essential part of trecento notation before circa $1390,{ }^{79}$ it disappears from French notation early in the century. ${ }^{80}$ Its subse-

\footnotetext{
${ }^{79}$ Machettus de Padua thoroughly explores the early trecento notation in his Pomerium, G. VECCHI (ed.), Marcheti de Padua Pomerium (s.l., 1961); The earliest examples of this system occur in Codex Rossi, vid. NinO PIRROTTA, Il Codice Rossi 215. In short, the value of this form in the Italian system depends on the divisiones and their context.

${ }^{80}$ In nova fert/Garrit gallus/(Neuma) in the Roman de Fauvel is an example of its early French use. The practice appears to have persisted in England as evident in the following examples: Cambridge, Conville and Gaius College 727/334, f.202r; Oxford, Bodley Library, Rawlinson liturg. d.3, No. 1; Oxford, New College 362, ff. 90v-91r. q.v. F. LL. HARRISON, English Church Music in the Fourteenth Century, in: New Oxford History of Music 3, ed. by DOM ANSELM HugHeS \& GeRARD ABRAHAM (London 1960), p. 82-106.
} 
quent "revival" in the French tradition of the ars subtilior possibly occurred through the influence of Italian composers, although in many cases its use in this repertoire is in fact not connected to the earlier practice since, in the ars subtilior it is often used to indicate proportional relationships, while in trecento notation it denotes relative length. ${ }^{81}$

The void black forms of En attendant esperance conforte, $\{$ and $\{$, found re spectively in Mod and Ch, are extremely rare, with the only comparable but clearly unrelated void black forms occurring in the keyboard music of Codex Faenza. ${ }^{82}$ It seems unlikely that the figure in En attendant has the value of half a minima as Willi Apel proposed since his solution requires that an inconsistent value be given to the previously mentioned void red minima with a downwards tail throughout the piece. ${ }^{83}$ Its nature also suggests that it is not a composite form as it has the tail for the smaller value above the note rather than in the usual position below.

In the Modena version of En attendant esperance, three-fold groups of the void black figure appear thrice in the $S$. These are shown in Figure 1. As can be seen, the first occurrence is followed by a single void red caudata, and the subsequent two occurrences are both followed by void red notes of one caudata, two minime and three caudate. In the actual MS, especially the last two instances, it is apparent that the first void red caudata has been written closer to the void black notes than the subsequent void red notes. Willi Apel had already noticed this apparent positioning of figures in the Mod version of En attendant esperance, and this fact is reflected in his transcription of this version where he groups the void black figures and single void red caudata in one perfection. ${ }^{84}$ However, Apel did not transcribe the void red caudate with a consistent value throughout the piece, and his mind was possibly swayed by the form shown in Figure 9 of Table 1 or Figure 10 in Table 2 when transcribing the void black form. By assuming that the void red caudata has a consistent value throughout this piece and that values of the three void black figures and one void red caudata equal one perfection, the value of the void black figure can be calculated to be five-sixths of a minima and represents a proportion of 3:5..$^{85}$ As shown by Figure 1, this interpretation requires no amendments to the notation, which is one of the central objectives of this new interpretation, and satisfies the requirement that all forms have a consistent value throughout the composition.

\footnotetext{
${ }^{81}$ Marchettus gives the analogy of the tail on a semibrevis to a tail on a brevis (actually a longa). This is a denotation of length. VECCHI, op. cit., pp. $110 \mathrm{f}$.

${ }^{82}$ vid. D. PlamenAC (ed.), Keyboard Music of the late Middle Ages in Codex Faenza 117 (s.l., 1972), p. ix. The form can be found on f. $63 \mathrm{v}(=42 \mathrm{v})$ and is equivalent to two ninth's of a minima. The notational system in the codex as a whole is close to the Italian system expressed by Antonio de Leno.

${ }^{83}$ APEL, Notation, p. 422.

${ }^{84}$ APEL, Notation, p. 422; IDEM, French Secular Music, pp. 167-169.

${ }^{85}$ cf. STONE, op. cit., pp. 157-163.
} 
Figure 1 : Use of figure caudate in the Mod version of En attendant esperance.

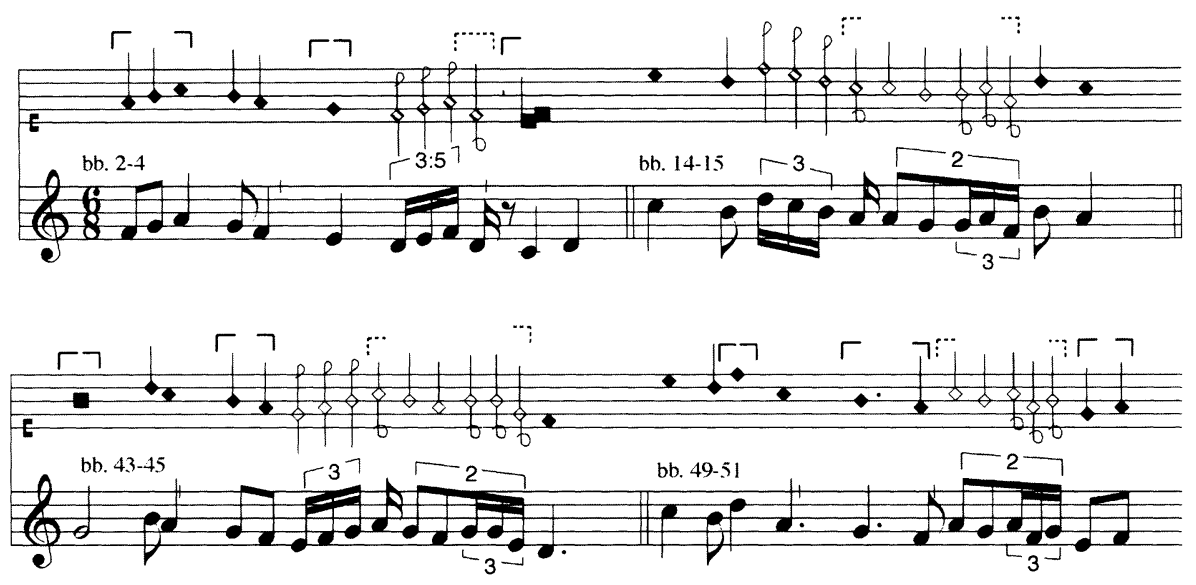

At first glance, such a value might be considered outside the perceived logic of the system, and contradicts values actually derived by theoretical methods. However, such proportions do result from the use of the previously mentioned particoloured forms encountered in this repertoire and some link to this device may be suggested. ${ }^{86}$ The odd nature of this void form in the context of other forms used in Senleches' works does hint at its unusual value. Whether any logic might be discovered to explain the nature of this form is debatable, and indeed the peculiarity of the form suggests it served as a trigger for the specialised memory of musicians experienced in this repertoire. ${ }^{87}$

In the case of $C h$, the value of five-sixths of a minima for this figure provides an unsatisfactory result for two out of three occurrences. Assuming that the value of the void black figure is two-thirds of a minima as Greene has in his edition $^{88}$ does satisfy the second and third occurrences. However, if this work is by Senleches, we might conclude that the scribe would use a figure consistent with other figures in the composition and with those in La harpe de melodie. This value is unambiguously expressed in La harpe de melodie by the form $\{$. As revealed by comparing Figures 1 and 2, the crux of the problem lies in variance between sources of the void red figures subsequent to threefold groups of these void black figures.

\footnotetext{
${ }^{86}$ A value may be determined by calculating the value of a half-black and half-white dragma and dividing it in half using the property of the tail on the upper stem as observable in the formation of semiminima.

${ }^{87}$ Mary Carruthers' discussion on the mechanisms used to aid memory in the Middle Ages includes many references to authors who recommend the use of outstanding images as an aid to memory, in The Book of Memory: A Study of Memory in Medieval Culture (Cambridge 1990), p. 133 et passim. Although this refers chiefly to illumination, a parallel can be drawn between grotesque figures and unusual note forms employed in the ars subtilior.

${ }^{88}$ GReENE, French Secular Music: Manuscript Chantilly Musée Condé, Second Part, pp. 56 f.
} 
Figure 2: Use of figure caudate in the Mod version of En attendant esperance.

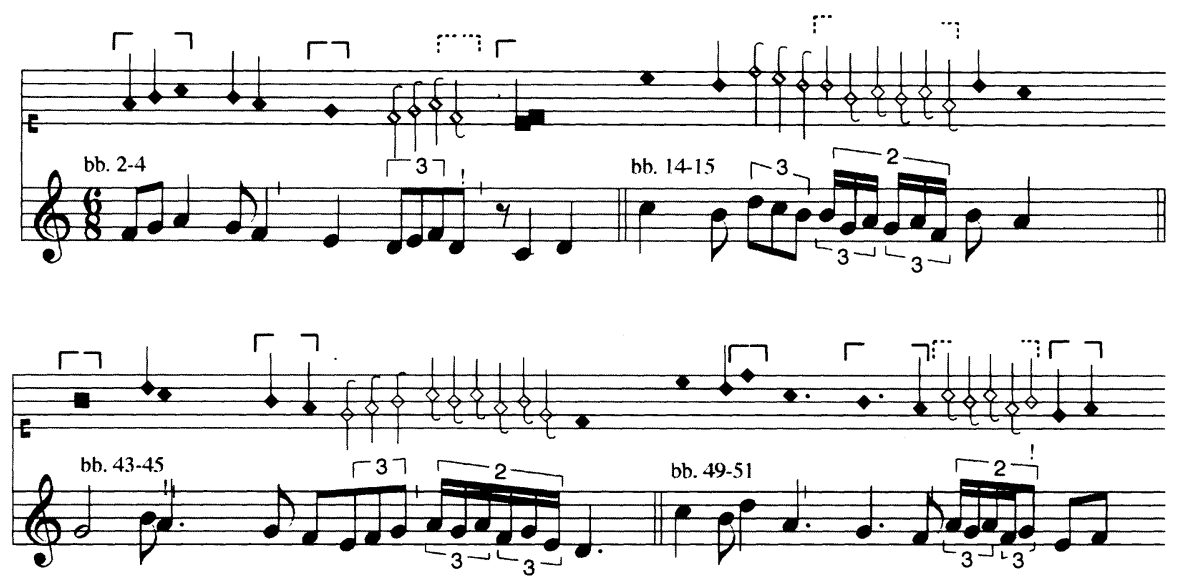

On account of this variance and the scribal errors in $C h$, one is encouraged to view this source of En attendant esperance conforte as extremely corrupted. In the case of the second and third occurrences, transcribing the void black figures as two-thirds of a minima does provide a partially satisfactory solution in conjunction with the void red figures. However, Greene's solution for the first occurrence is questionable for two reasons: the first void red minima caudata is given a value of one-third of a minima, which is inconsistent with its transcribed duration elsewhere in the composition, and the second semibrevis of the first ligature cum opposita proprietate is transcribed as perfect, whereas it must be imperfected by the subsequent minima. ${ }^{89}$

Table 4 (s. p. 159) summarises the semibreves caudate found in the music of Senleches. Whilst figures 1 and 6 in this table represent the same duration, they do not represent a conundrum when attempting to represent Senleches' notational style as a whole. The context of the forms is significantly different with one occurring in perfect tempus and the other in imperfect tempus. However, the observed parallel usage in Tel me voit and Que maior pena and the observable lack of ambiguity apparent in this manner of notation may suggest that the scribe of Mod altered the note form.

${ }^{89}$ cf. STONE, op. cit., pp. $139 \mathrm{f}$. 
Table 4: Semibreves caudate found in the Music of Jacob de Senleches.

\begin{tabular}{|c|c|c|c|c|}
\hline Form & Value & Mensuration & Location & Comments \\
\hline 1. & $1 \frac{1}{3}$ & {$[3,2]$} & Tel me voit & $\begin{array}{c}\text { Perfect division of imperfect tempus, } \\
\text { (imperfected through coloration) } \\
\text { contrary to normal imperfect } \\
\text { division }(3: 2) \text {. }\end{array}$ \\
\hline 2. & 2 & {$[2,3]$} & $\begin{array}{l}\text { La harpe de } \\
\text { melodie }\end{array}$ & $\begin{array}{c}\text { Perfect division of imperfect tempus } \\
\text { contrary to normal imperfect } \\
\text { division }(3: 2) \text {. }\end{array}$ \\
\hline 3. & $1 / 2$ & {$[2,3]$} & $\begin{array}{c}\text { En attendant } \\
\text { esperance conforte }\end{array}$ & $\begin{array}{l}\text { Perfect division of void red } \\
\text { prolation contrary to normal } \\
\text { imperfect division }(3: 2) .\end{array}$ \\
\hline 4. $\hat{q}$ & $2 / 3$ & {$[2,3]$} & $\begin{array}{l}\text { La harpe de } \\
\text { melodie }\end{array}$ & $\begin{array}{l}\text { Perfect division of void black } \\
\text { prolation contrary to normal } \\
\text { imperfect division }(3: 2) \text {. }\end{array}$ \\
\hline & $1 \frac{1 / 2}{2}$ & {$[2,3],[3,2]$} & $\begin{array}{l}\text { Tel me voit and } \\
\text { La harpe de } \\
\text { melodie }\end{array}$ & $\begin{array}{l}\text { Four-fold division of tempus }(4: 3) \\
\text { or imperfect division of prolation } \\
\text { contrary to normal perfect division. }\end{array}$ \\
\hline 6.8 & $11 / 3$ & {$[2,3]$} & $\begin{array}{l}\text { La harpe de } \\
\text { melodie }\end{array}$ & $\begin{array}{l}\text { Perfect division of imperfect tempus } \\
\text { contrary to normal imperfect } \\
\text { division }(3: 4) \text {. }\end{array}$ \\
\hline 7. & $5 / 6 ?$ & {$[2,3]$} & $\begin{array}{c}\text { En attendant } \\
\text { esperance conforte }\end{array}$ & $\begin{array}{l}\text { Perfect division of the remainder of } \\
\text { a perfection imperfected by figure } \\
3 \text { ? }\end{array}$ \\
\hline
\end{tabular}




\section{Conclusion}

Aside from establishing the relative durations of figures in Senleches' music, it has been the aim of this paper to demonstrate that the mechanisms used to determine the form of special figures were based on principles which stem from French notation, and not Italian. The most glaring fact which confronts us is that apart from the use of particolored breves and semibreves, composite note forms modelled on the principles of the Tractatus Figurarum are not found in Senleches' music. During the late fourteenth century, these forms appear to be favoured of music by Italian composers in the ars subtilior style which would seems to contradict the assertion made by the author of the Tractatulus de figuris et temporibus that these figures are French. However, the primary concern of the Tractatus author is to rationalise an existing system of notation. This quite possibly was the notation employed in the sources of Senleches' music.

The notation of Senleches differs appreciably from the system of the Tractatus Figurarum in that the latter does not rely chiefly on context to determine the value of the figure. In Senleches' music, each figure is tied closely to the mensuration and the properties of figures within those mensurations. However, several observations have been made in the course of this discussion pointing to historical influences present in the notation. With regards to coloration including the use of void red figures, we can discern purely French devices. However, it is conceded that void red figures are mimicking Italian notation. The nature of the figure caudate is less certain. Based upon the dependency of these figure upon mensural context and the established behaviour of coloration, it is likely that these figures were conceived within the French tradition as an alternative to those figures in the Tractatus Figurarum. The fact that Senleches' notation, which relies chiefly on proportional relationships, shares traits with the work of another composer of this period, namely Rodericus, does suggest that there was a connection between these composers who utilised this now extremely rare set of conventions and note forms. 
En attendant, esperance conforte
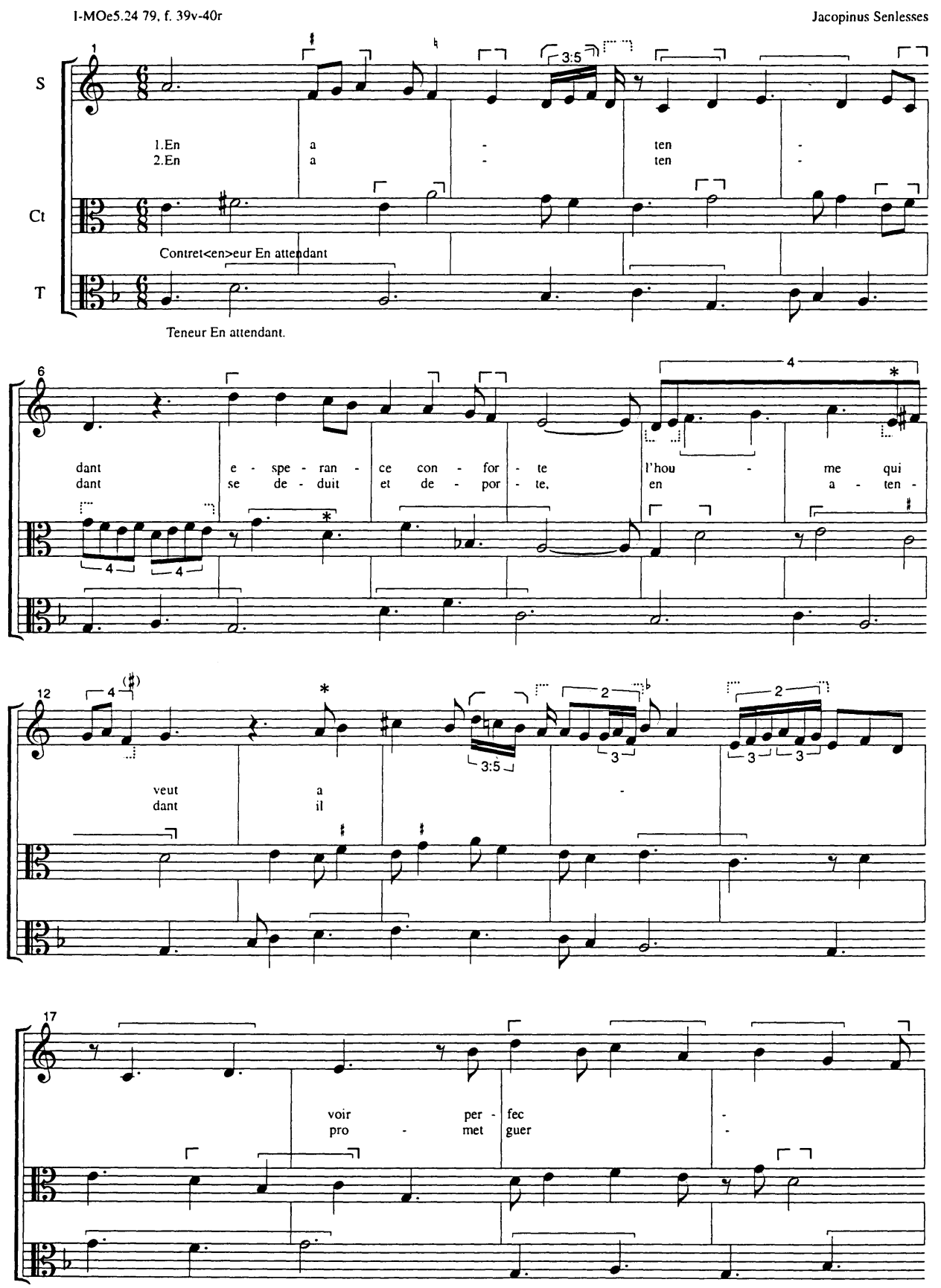

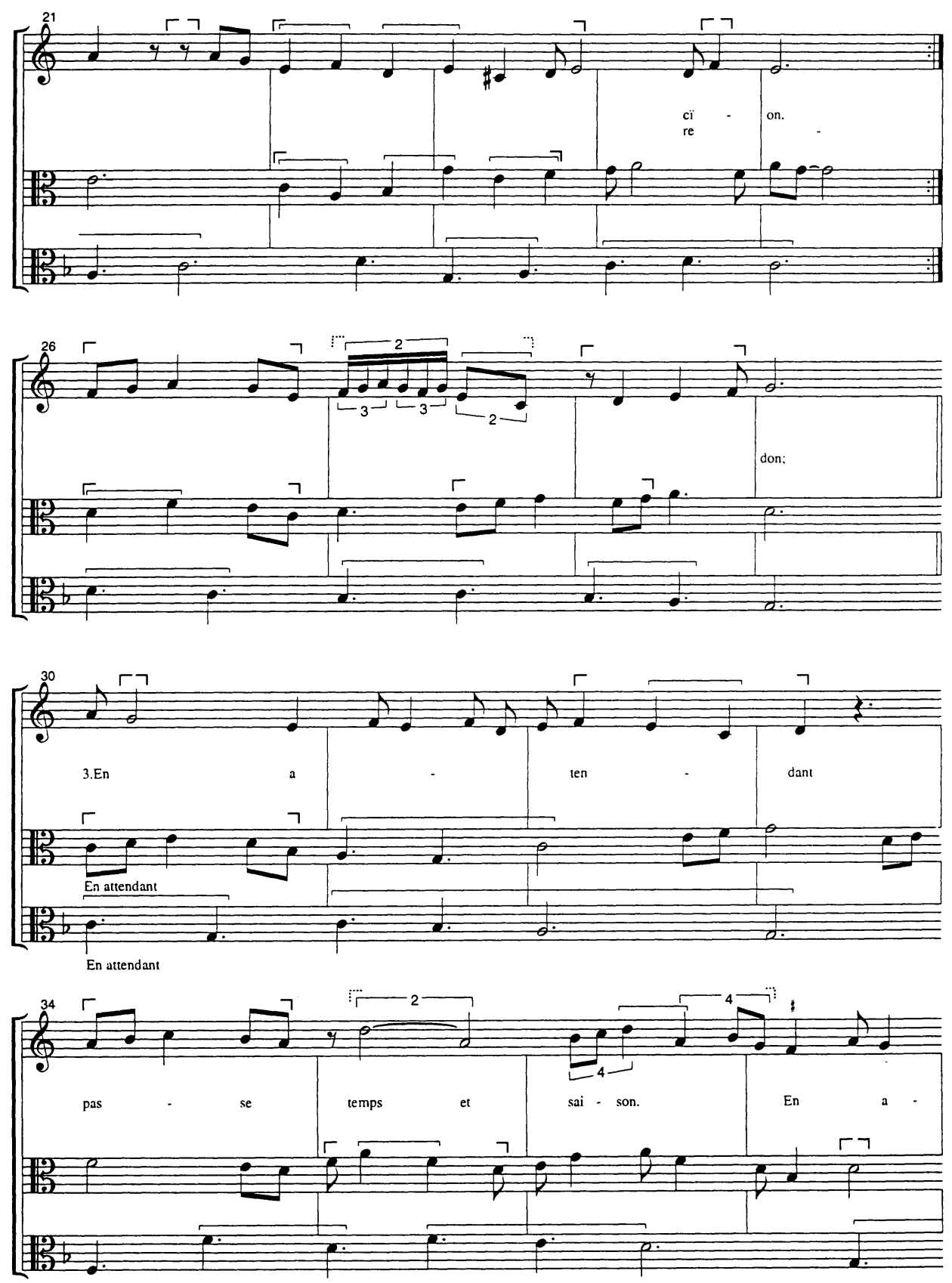

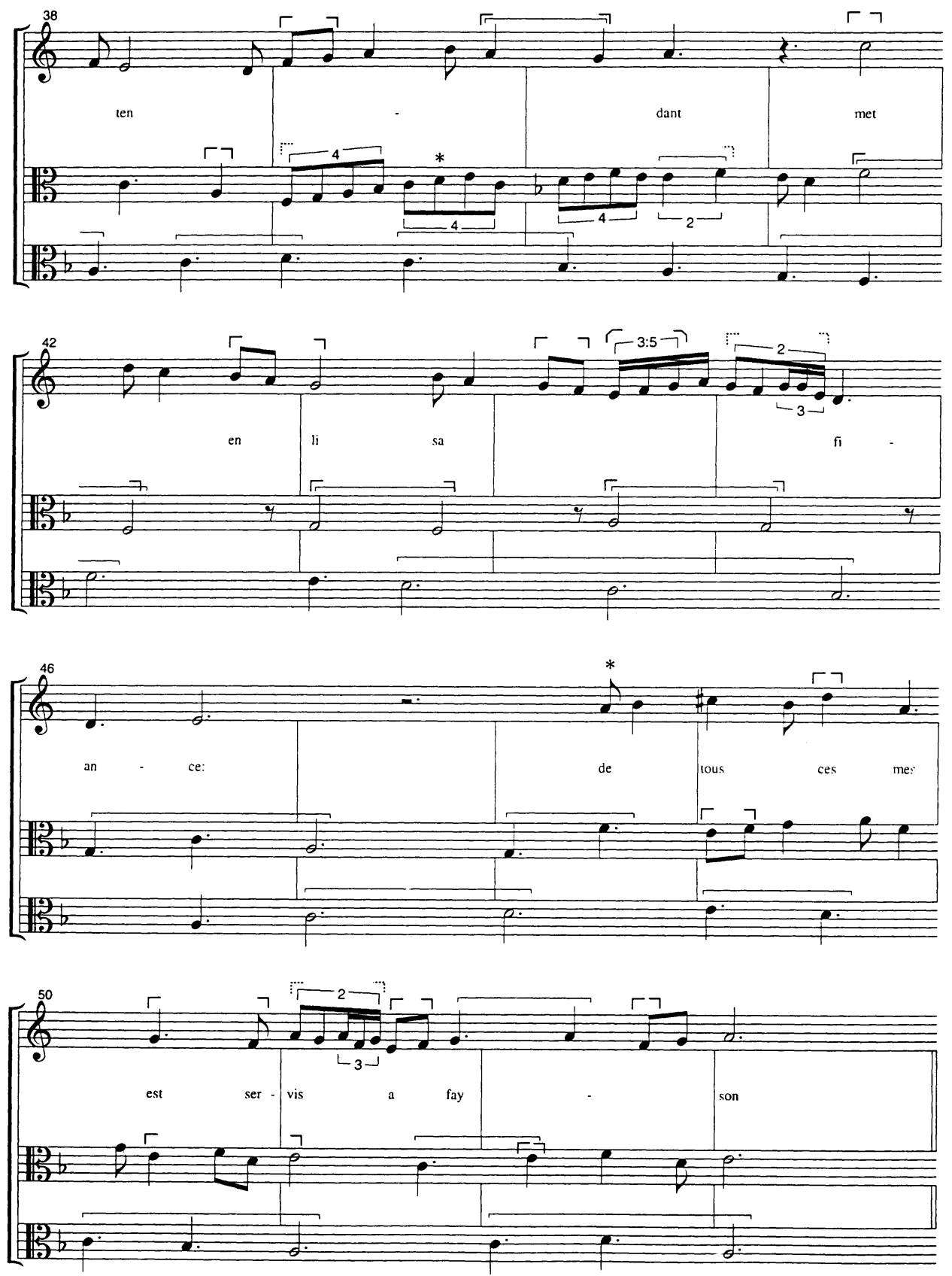


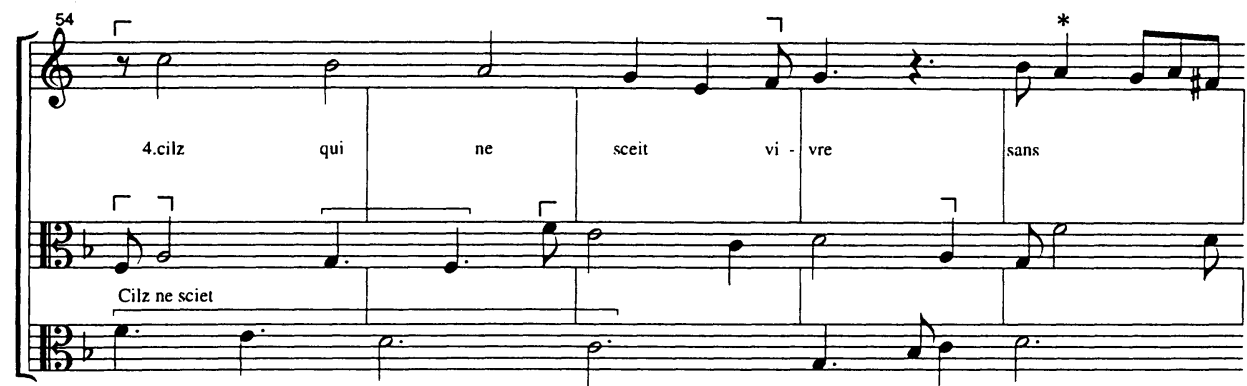

Cilz qui ne sceit vivre
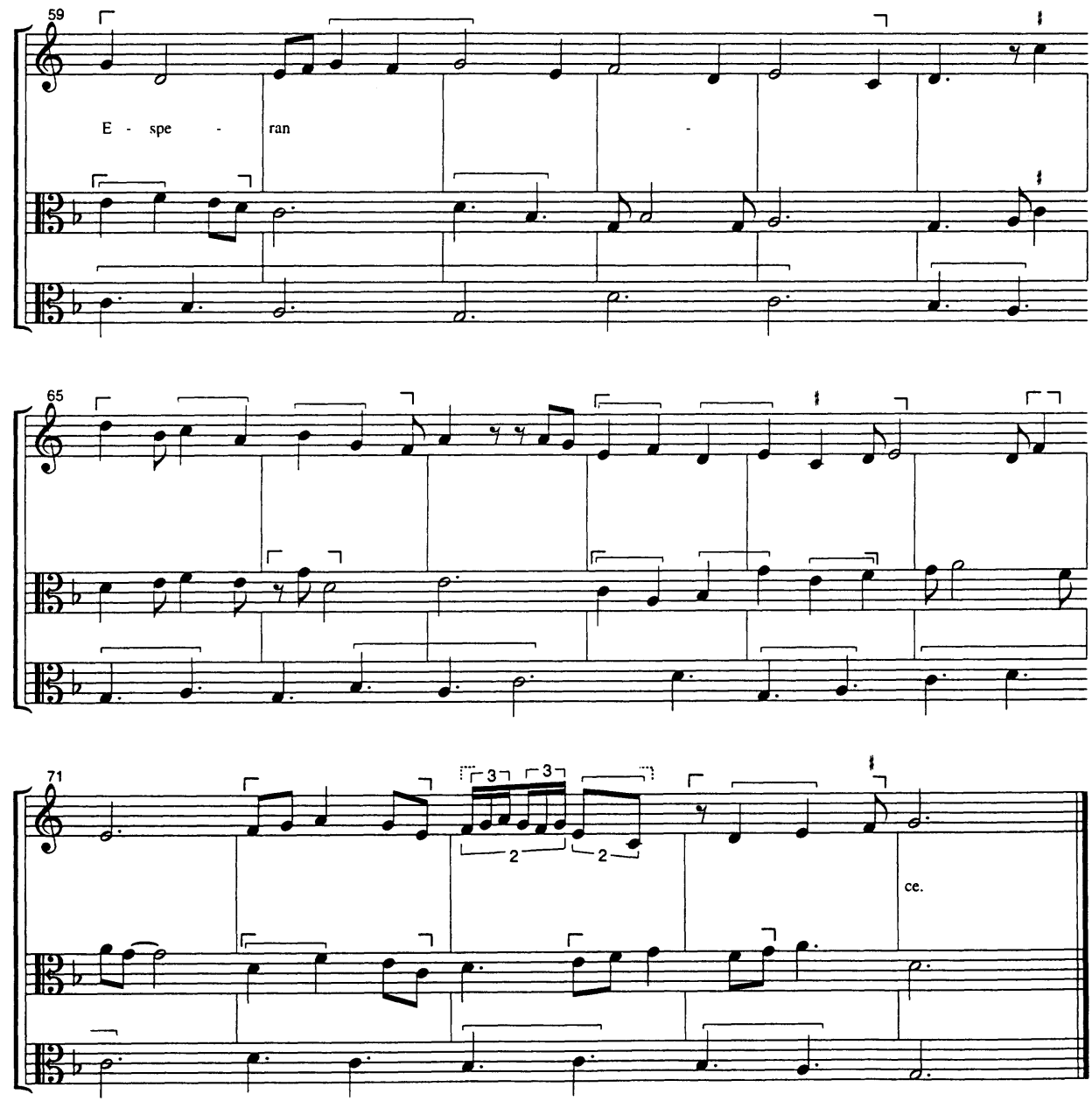